\title{
Peak expiratory flow rate of primary school children in high and low air pollution level areas
}

\author{
Ismart Edy Hasibuan, MD; M Nur Supriatmo, MD; A Faisal, MD; \\ Gabriel Panggabean, MD; Ridwan M Daulay, MD; Zakaria Siregar, MD; Helmi M Lubis, MD
}

\begin{abstract}
Background Chronic inhalation of air pollutants may cause bronchoconstriction, bronchiolitis, and edema of airway, thus alter lung volume. To measure the lung volume, a simple lung function test, the peak expiratory flow rate (PEFR), can provide a feature of lung volume in liters/minute.

Objective The purpose of this study was to measure PEFR values of primary school children in a high air pollution level area (Medan) and compare the results with the PEFR values of those in a low air pollution level area (Tebing Tinggi).

Methods A cross sectional study was conducted on primary school children (10-12 years of age) during May-July 2000 in Medan and Tebing Tinggi. Data were obtained by questionnaires. Physical examination included age, sex, height, weight, and PEFR value. PEFR values were measured by Mini Wright peak expiratory flow meter (MPFM) from three blows. The highest volume was taken as the PEFR value. Statistical analysis was done by t-test and $p<0.05$ was considered significant.

Results There were 212 primary school children eligible for this study; 107 came from the high air pollution level area and 105 from the low air pollution level area. The PEFR values did not differ significantly between the two groups $(p>0.05)$

Conclusion PEFR values in a high air population level area were not statistically different compared with those in low air pollution level area [Paediatr Indones 2003;43:10-13].
\end{abstract}

Keywords: peak expiratory flow rate (PEFR), high pollution level, low pollution level, primary school children.

I nhalation of air pollutants may result in local (only in the lungs) or systemic (hematologic) effects and may also be acute or chronic. The acute effects appear after contact with agents, such as cough after ozone inhalation. The chronic effects usually appear after prolonged exposure, such as mesothelioma after long time inhalation of asbestos.
The major pollutant agents in the atmosphere which may influence the lungs are $\mathrm{SO}_{2}, \mathrm{NO}_{2}$, and $\mathrm{O}_{3}{ }^{3-5}$ which can cause bronchoconstriction, bronchiolitis, edema of the airway and thus alter the lung volumes. Peak expiratory flow rate (PEFR) is a simple lung test which could be used to measure the volume feature of the lungs. Factors which may influence PEFR include age, sex, height, weight, air humidification, air condition, etc. Lung function tests are usually performed to aid diagnosis, evaluate the response of therapy, plan rehabilitation, promote the health status, and for epidemiologic survey or screening. 2,3,6-9 The aim of our study was to evaluate PEFR values among school children (10-12 year-old) in a high and a low air pollution level areas.

\section{Methods}

A cross sectional study was conducted during May to July 2000 among school children (10-12 years old) in a high and a low air pollution level area. The subjects

From the Department of Child Health, Medical School, North Sumatera University_Adam Malik Hospital, Medan, Indonesia

Reprint requests to: Ismart Edy Hasibuan, MD, Department of Child Health, Medical School, North Sumatera University/Adam Malik Hospital, Medan, Indonesia; Tel./Fax. 62-61-836 1721 
were obtained by simple random sampling. Subjects were primary school children in Tebing Tinggi as the low air pollution level area and in Medan as the high air pollution level area. The inclusion criteria were primary school children without history of recurrent dyspnea or wheezing; without cough, sore throat, fever; without purulent otitis media; with no chest wall deformity (scoliosis, lordosis, etc); without condition which might alter PEFR value (hernia, cleft lip, heart failure etc); and who were cooperative during the test. Exclusion criteria included refusal to join the test or uncooperative during the test.
PEFR value was measured by Mini Wright peak flow meter (MPFM) (Vitalograph Pulmonary Monitor, Vitalograph (Ireland) Ltd, Faris Co,Clark Clement Ref. Ireland International Pats, applied for British Patent No.1500283, 650 liters/minute). The children were instructed to blow MPFM for three times after first taking a deep inspiration. The highest PEFR was taken as the PEFR value. Body height was measured by a plastic meter scale (Butterfly) and body weight was measured by a standing scale. All data were recorded and analyzed by SPSS computer program version 7.0. To assess the difference of PEFR value between the two groups, we used the student t-test.

Table 1. Characteristics and PEFR values of subjects

\begin{tabular}{|c|c|c|c|c|}
\hline $\begin{array}{l}\text { Characteristics and } \\
\text { PEFR values }\end{array}$ & $\begin{array}{l}\text { High air pollution } \\
(n=107)\end{array}$ & $\begin{array}{l}\text { Low air pollution } \\
(n=105)\end{array}$ & $p$ value & \\
\hline \multicolumn{5}{|l|}{ Sex } \\
\hline \multicolumn{5}{|l|}{ Male: } \\
\hline 10 years & 19 & 17 & & \\
\hline 11 years & 16 & 16 & & \\
\hline 12 years & 20 & 20 & & \\
\hline \multicolumn{5}{|l|}{ Female } \\
\hline 10 years & 14 & 18 & & \\
\hline 11 years & 19 & 16 & & \\
\hline 12 years & 19 & 21 & & \\
\hline \multicolumn{5}{|l|}{ Body weight $(\mathrm{kg})$} \\
\hline \multicolumn{5}{|l|}{ Male: } \\
\hline 10 years & $23.26 \pm 1.85$ & $22.12 \pm 1.80$ & 0.07 & $\mathrm{NS}^{*}$ \\
\hline 11 years & $25.37 \pm 2.39$ & $24.00 \pm 2.13$ & 0.09 & $\mathrm{NS}^{*}$ \\
\hline 12 years & $30.30 \pm 6.81$ & $27.59 \pm 4.56$ & 0.17 & $\mathrm{NS}^{*}$ \\
\hline \multicolumn{5}{|l|}{ Female } \\
\hline 10 years & $25.36 \pm 3.63$ & $23.28 \pm 2.58$ & 0.07 & $\mathrm{NS}^{*}$ \\
\hline 11 years & $31.26 \pm 6.96$ & $31.00 \pm 4.15$ & 0.89 & $\mathrm{NS}^{*}$ \\
\hline 12 years & $31.79 \pm 8.53$ & $32.81 \pm 6.60$ & 0.67 & $N S^{*}$ \\
\hline \multicolumn{5}{|l|}{ Body Height $(\mathrm{cm})$} \\
\hline \multicolumn{5}{|l|}{ Male: } \\
\hline 10 years & $126.31 \pm 4.08$ & $123.82 \pm 5.25$ & 0.12 & NS* \\
\hline 11 years & $126.94 \pm 4.52$ & $125.94 \pm 4.33$ & 0.53 & NS* \\
\hline 12 years & $134.80 \pm 6.42$ & $134.41 \pm 7.30$ & 0.86 & NS* \\
\hline \multicolumn{5}{|l|}{ Female } \\
\hline 10 years & $127.50 \pm 3.50$ & $125.67 \pm 4.77$ & 0.24 & NS* \\
\hline 11 years & $135.84 \pm 3.44$ & $136.00 \pm 3.85$ & 0.90 & $\mathrm{NS}^{*}$ \\
\hline 12 years & $134.84 \pm 6.87$ & $136.81 \pm 5.60$ & 0.33 & $\mathrm{NS}^{*}$ \\
\hline \multicolumn{5}{|l|}{ PEFR (L/min) } \\
\hline \multicolumn{5}{|l|}{ Male: } \\
\hline 10 years & $239.47 \pm 39.47$ & $252.94 \pm 21.44$ & 0.22 & $\mathrm{NS}^{*}$ \\
\hline 11 years & $271.87 \pm 36.37$ & $262.62 \pm 35.21$ & 0.63 & $\mathrm{NS}^{*}$ \\
\hline 12 years & $300.50 \pm 29.40$ & $285.29 \pm 55.24$ & 0.30 & $\mathrm{NS}^{*}$ \\
\hline \multicolumn{5}{|l|}{ Female } \\
\hline 10 years & $221.43 \pm 25.68$ & $238.89 \pm 32.34$ & 0.11 & $\mathrm{NS}^{*}$ \\
\hline 11 years & $276.31 \pm 42.06$ & $268.75 \pm 40.31$ & 0.59 & $\mathrm{NS}^{*}$ \\
\hline 12 years & $271.05 \pm 34.02$ & $288.09 \pm 54.55$ & 0.25 & NS* \\
\hline
\end{tabular}

$\mathrm{NS}=$ not significant

Values are given as mean \pm SD or as the number (percentage) of subjects

* unpaired test 


\section{Results}

There were 212 children in this study, 107 were from the high air pollution level area and 105 from the low air pollution level area. The sex distribution was 105 males and 107 females. The age and weight distributions were not statistically different $(p>0.05)$ in both areas. There was also no statistical difference in age and height between both groups ( $p>0.05)$. The PEFR values showed that there was no significant difference in PEFR values between children from the high and the low air pollution level areas $(p>0.05)$ (Table 1).

\section{Discussion}

Lung function test is an important tool to evaluate the management of lung disease i.e., to aid diagnosis, to evaluate the success of therapy, to predict the prognosis of lung and airway disease, and for screening or epidemiologic survey. ${ }^{7-17} \mathrm{~A}$ long time ago, lung function assessment was very simple, as in the Snider Match Test, in which one is asked to blow the fire of a match from the distance of $\pm 15 \mathrm{~cm}$, and if he fails to put off the fire, it means that his VEP-1 is $<100$ $\mathrm{ml} .^{8-15}$ Nowadays the standard equipment to measure the peak expiratory flow rate is Wright Peak flow meter made by BM Wright and GB McKerrow (1959). Mini Wright peak flow meter is a simplified modification of Wright peak flow meter. The PEFR value in MPFM was determined empirically according to measurements by Wright peak flow meter. ${ }^{7,12-17}$ The PEFR assessment with MPFM has been used widely as a way to asses the lung function accurately because it is simple and can be practically performed at home or a doctor's office. ${ }^{7}$

A study in a high photochemical oxidants area showed that long time exposure correlated with increase of symptoms of lung disease and few or mild disturbances in lung function which decreased after 5 years later. $3,5,6$

In industrialized and developing countries, both in rural and urban areas, air pollution is a serious and growing problem. In South Africa's Eastern Transvaal Highveld region, pollution is due to coal fires; in Riga, Latvia, due to automobiles emission; and in Santiago, Chile, because of uncontrolled industrial pollution. ${ }^{5}$
In Medan, some areas, both in the centre of the city and the industrialized area, had higher concentration of air pollution than that was recommended. ${ }^{21}$ While in Tebing Tinggi we found that air pollution concentration was still in the recommended value or ambient level.

In this study, subjects were grouped by sex and age of $10,11,12$ year-old. Of the 212 school children included, in the 10 year old boys and girls group and also in the 11 and 12 year old group, PEFR values between the high and the low air pollution level area were not statistically different $(p>0.05)$. According to PEFR values by the Godfrey normogram, the PEFR values of subjects in the high air pollution level area were $>90 \%$ in 'mean level area' or more, while in the low air pollution area, the PEFR values were $>95 \%$ in 'mean level area' or more (-95\%$+95 \%)$. Lung function was influenced by smoking, race, local air quality, age, sex, daily activity, posture, geography, air humidity, air pollution, etc. The exact air pollution level or time of exposure that may influence the lungs and airways cannot be measured correctly (especially for 3 major pollutants i.e., $\mathrm{SO}_{2}$, $\mathrm{NO}_{2}, \mathrm{O}_{3}$ ). A study of ozone exposure at $0.12 \mathrm{ppm}$ for $1-2$ hours showed decreased FEV-1 in 10-20\% healthy subjects, followed by symptoms of respiratory disorders such as cough, dyspnea, and wheezing. High ozone concentration also induced asthma. A study showed that high $\mathrm{NO}_{2}$ exposure could make diffuse alveolar and terminal bronchial damage and $\mathrm{NO}_{2}$ exposure of more than $150 \mathrm{ppm}$ can cause death. ${ }^{3-5,21-23}$

We concluded that PEFR values of school children in the high air pollution level area compared with those in the low air pollution level area were not statistically different.

\section{References}

1. Guyton AC. Ventilasi paru-paru. In: Dharma A, Lukmanto P, translators. Fisiologi kedokteran. Jakarta: EGC; 1983. p. 1-13.

2. Wirjodiardjo M. Evaluasi klinik fungsi paru dalam pemecahan masalah kesehatan anak. In: Rahajoe N, Rahajoe NN, Boediman I, editors. Buku naskah lengkap pendidikan kedokteran berkelanjutan anak XXXIII. Jakarta: FKUI; 1994. p. 45-73. 
3. Boushey HA, Sheppard D, Tager I. Air pollution. In: Murray JF, Nadel JA, editors. Textbook of respiratory medicine. $2^{\text {nd }}$ ed. Philadelphia: WB Saunders Co; 1994. p. 2032-45.

4. Aditama TY. Polusi udara dan kesehatan. Jakarta: Arcan; 1995. p. 11-4.

5. Wijetilleke L, Karnaratne SAR. Air quality management: considerations for developing countries. Washington: World Bank; 1995. p. 9-40.

6. Lemen RJ. Pulmonary function testing in the office, clinic, and home. In: Chernick V, Kendig EL, editors. Kendig's disorders of the respiratory tract in children. $5^{\text {th }}$ ed. Philadelphia: WB Saunders Co; 1990. p. 147-53.

7. Wenzel SE, Larsen GL. Assessment of lung function: pulmonary function testing. In: Bierman CW, Pearlman DS, Shapiro GG, Busse WW, editors. Allergy, asthma, and immunology from infancy to adulthood. Philadelphia: WB Saunders Co; 1996. p. 156-72.

8. Hodgkin JE. Routine pulmonary function tests. In: Burton GG, Hodgkin JE, editors. Respiratory care a guide to clinical practice. $2^{\text {nd }}$ ed. Philadelphia: JB Lippincott Co; 1994. p. 23-8.

9. Stark JE, Shneerson JM, Higenbottam T, Milstein BB. Manual ilmu penyakit paru. Jakarta: Binarupa Aksara; 1990. p. 48-54.

10. Miller LG, Kazemi H. Manual of clinical pulmonary medicine. New York: MC Graw Hill Book Co; 1983. p. 33-41.

11. Wirjodiardjo M, Said M, Budiman HI Perbandingan hasil pengukuran peak flow rate antara mini wright peak flow meter dan spirometer elektronik pada anak. Maj Kedok Ind 1992;42:575-85.
12. WHO. In: Wijaya C, Suyono J, translators. Deteksi dini penyakit akibat kerja. Jakarta: EGC; 1995. p. 213-20.

13. Santoso H. Peak expiratory flow rate: Harga standar untuk anak-anak normal berumur 8-15 tahun. Medika 1991;17:299-304.

14. Miller MR, Quanjer PH. Peak flow meters: a problem of scale. BMJ 1994;308:548-9.

15. Aditama TY. Mangunnegoro H, Fachrurodji H, Depari, Saharawati. Penggunaan arus puncak ekspirasi maksimum dalam penilaian faal paru. Medika 1987;13:670-2.

16. Gold WM. Pulmonary function test. In: Murray JF, Nadel JA, editors. Textbook of respiratory medicine. $2^{\text {nd }}$ ed. Philadelphia: WB Saunders Co; 1994. p. 798-805.

17. Alsagaff $\mathrm{H}$. Perlukah dibuat nilai standard faal paru untuk orang Indonesia?. Medika 1990;16:8-9

18. Sly PD, Cahill P, Willet P, Burton P. Accuracy of mini peak flow meters in indicating changes in lung function in children with asthma. BMJ 1994;308:572-4.

19. Higgenbottam T. Respiratory function test. Medicine International 1986:1393-9

20. Badan Pengendalian Dampak Lingkungan Daerah. Neraca kualitas lingkungan hidup daerah Propinsi Daerah Tingkat I Sumatera Utara tahun 1998. Medan: Bapendal; 1998. p. 145-6.

21. Sastrawijaya AT. Pencemaran lingkungan. Surabaya: Rineka Cipta; 1991. p. 165-201.

22. Oceandy D, Widyantoro A, Armanto RP. Gangguan sistem pernafasan dan faal paru pada petugas kebersihan kota. Medika 1996;22:775-8.

23. Sukar. Pengaruh kesehatan oksida nitrogen dari emisi mesin diesel. Medika 1986;12:959-62. 